\title{
Federal Child Nutrition Programs are Important to Rural Households
}

\author{
BARBARA WAUCHOPE AND ANNE SHATTUCK
}

$\mathrm{F}$ our government nutrition programs are so vital to children's well-being that one-third of federal expenditures on food assistance for children are devoted to them. ${ }^{1}$ They are the National School Lunch Program; the School Breakfast Program; the Women, Infants, and Children (WIC) program; and the Child and Adult Care Food Program. With the country in severe recession and families relying on these programs more than ever, Congress is scheduled to reauthorize their funding legislation, the Child Nutrition and Women, Infants, and Children Reauthorization Act of 2004. The reauthorization process provides the opportunity to consider the programs again, particularly whom they are serving and the benefits they provide.

In this brief, we use data from the U.S. Census Bureau's December 2007 Current Population Survey, the most recent population data available on all four programs, to look specifically at participation by one segment of the population: rural households. Families in rural America could be overlooked in discussions of the child nutrition programs because the largest numbers of low-income families eligible for the programs live in urban areas; however, the proportion of families who are income-eligible is higher in rural areas. ${ }^{2}$

\section{Key Findings}

- Of the estimated 6.2 million rural households with children in the United States, approximately 29 percent participate in at least one of the four major federal child nutrition programs.

- Although about 2.8 million rural households with children are income-eligible for the child nutrition programs, roughly 43 percent of those eligible do not participate in any of the four programs.

- Rural household participation rates in the South are higher than the rates nationally for all four programs.

\section{Rural Households Rely on Child Nutrition Programs}

Rural America is home to approximately 6.2 million households with children. Of these households, an estimated 29 percent participate in at least one of the four child nutrition programs; about 20 percent participate in two or more. Rates of participation are higher among rural than suburban households and similar to central cities. When suburban and central city rates are combined into a metro area average, participation in the School Breakfast Program and WIC is almost 50 percent higher in rural than in metro areas (see Table 1). Rates for the Child and Adult Care Food Program and National School Lunch Program are about 31 percent and 37 percent higher, respectively. These differences are similar to those in the federal Supplemental Nutrition Assistance Program (Food Stamp Program). ${ }^{3}$

Many more children are eligible but do not use the services. Out of the estimated 2.8 million income-eligible rural households with children, ${ }^{4}$ about 43 percent do not participate in any of the four child nutrition programs. Nonparticipation ranges from approximately 1.5 million for the National School Lunch Program (55 percent of those eligible) to 2.6 million (92 percent) for the Child and Adult Care Food Program (see Figure 1).

The low rates of participation in the Child and Adult Care Food Program and WIC owe in part to categorical requirements. ${ }^{5}$ For example, child care providers choose to participate in the Child and Adult Care Food Program, which reimburses them for meals and snacks served to children. However, children can access this food only by enrolling in a participating child care program. Rural children are more likely to be cared for in relatives' homes than in the centers and family child care homes where the Child and Adult Care Food Program is available. ${ }^{6}$ Families may be excluded from participating in the WIC program because of narrower eligibility criteria than the other nutrition programs. WIC requires that an eligible household have a mother who is either pregnant or has a child under age $5 .^{7}$ 


\section{TABle 1. PARTicipation IN FOUR FEDERAL CHILD NUTRITION PROGRAMS IN THE UNITED STATES: RURAL AND METROPOLITAN HOUSEHOLDS WITH CHILDREN 18 AND UNDER ${ }^{\mathrm{a}}$}

\begin{tabular}{|c|c|c|c|c|}
\hline & Total & Rural & Suburban & $\begin{array}{l}\text { Centra } \\
\text { city }\end{array}$ \\
\hline $\begin{array}{l}\text { Total number of households with } \\
\text { children } 18 \text { or under (in millions) }\end{array}$ & $41.5^{\mathrm{b}}$ & 6.2 & 18.2 & 11.2 \\
\hline \multicolumn{5}{|l|}{ National School Lunch Program } \\
\hline $\begin{array}{l}\text { Number of households with } \\
\text { children participating (in millions) }\end{array}$ & 7.1 & 1.4 & 2.2 & 2.5 \\
\hline $\begin{array}{l}\text { Percent of households with } \\
\text { children participating }\end{array}$ & $17.2 \%$ & $22.4 \%$ & $12.0 \%$ & $22.7 \%$ \\
\hline \multicolumn{5}{|l|}{ School Breakfast Program } \\
\hline $\begin{array}{l}\text { Households with children } \\
\text { participating (in millions) }\end{array}$ & 5.5 & 1.1 & 1.6 & 2 \\
\hline $\begin{array}{l}\text { Percent of households with } \\
\text { children participating }\end{array}$ & $13.2 \%$ & $18.3 \%$ & $8.7 \%$ & $17.9 \%$ \\
\hline \multicolumn{5}{|l|}{ Women, Infants and Children } \\
\hline $\begin{array}{l}\text { Households with a mother or } \\
\text { child participating (in millions) }\end{array}$ & 2.8 & 0.6 & 0.8 & 1 \\
\hline $\begin{array}{l}\text { Percent of households with } \\
\text { a mother or child participating }\end{array}$ & $6.8 \%$ & $9.4 \%$ & $4.3 \%$ & $9.2 \%$ \\
\hline \multicolumn{5}{|l|}{ Child and Adult Care Food Program } \\
\hline $\begin{array}{l}\text { Households with children } \\
\text { receiving food at day care or } \\
\text { Head Start }^{c} \text { (in millions) }\end{array}$ & 1.2 & 0.2 & 0.4 & 0.4 \\
\hline $\begin{array}{l}\text { Percent of households with } \\
\text { children receiving food } \\
\text { at day care or Head Start }\end{array}$ & $3.0 \%$ & $3.8 \%$ & $2.0 \%$ & $4.0 \%$ \\
\hline
\end{tabular}

Source: U.S. Census Bureau, December 2007 Current Population Survey

a. No statistically significant differences were found between numbers of rural and central city participants for any of the four programs. Rural and suburban household participation is statistically significant for all four programs at $\mathrm{p}<.001$.

b. The total of 41.5 million households with children under 18 includes a group that resides in unidentified metropolitan areas, for example, either suburban or central city, that are not included in this table. They represent 14 percent of the 41.5 million total.

c. Current Population Survey respondents are not asked if their children participate in the Child and Adult Care Food Program but instead if they receive food from their day care or Head Start program. Respondents are unlikely to know the name of the program funding their children's food. Because all the respondents that participated are in low-income households, it is highly probable that the child care and Head Start programs they attend participate in the Child and Adult Care Food Program.
FIGURE 1. NONPARTICIPATION IN CHILD NUTRITION PROGRAMS AMONG INCOME-ELIGIBLE RURAL HOUSEHOLDS WITH CHILDREN 18 AND UNDER

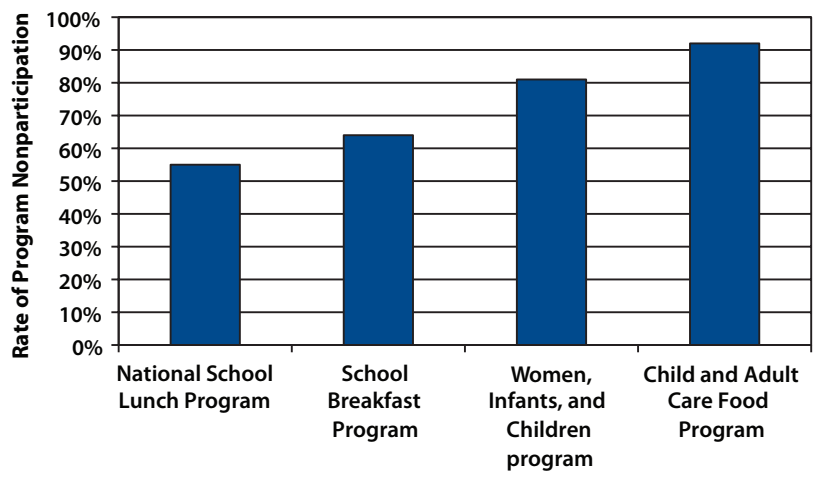

\section{Participation Rates are Highest in the South}

Most of the rural households that participate in these child nutrition programs live in the South and Midwest, the most rural regions of the country (see Table 2). Rural poverty is highest in the South, where nearly one in three children under six are poor. ${ }^{8}$ Rural families there are more likely to be income-eligible than in any other region. There are roughly 1.4 million eligible rural households in the South, which is about one-half of all rural southern households with children. Consequently, participation rates in the South are higher than the rates nationally for all four programs. More than one-quarter of all rural households with children in the South, for example, participate in the National School Lunch Program, and about 23 percent participate in the School Breakfast Program.

\section{TABle 2. PARTICIPATION IN FOUR FEDERAL CHILD NUTRITION PROGRAMS IN THE UNITED STATES BY REgION: ${ }^{\text {a PERCENTAge OF ALL RURAL HOUSEHOLDS }}$ WITH A CHILD 18 AND UNDER}

\section{U.S. Northeast Midwest South West}

National School

Lunch Program

School Breakfast

Program

Child and Adult Care

Food Program

Women, Infants and

Children (WIC) program

20

18

27

18

15

13

23

Source: U.S. Census Bureau, December 2007 Current Population Survey

a. Statistical differences between the South and the other regions are significant $(\mathrm{p}<.05)$ for the two school meals programs: National School Lunch Program and School Breakfast Program. For the Child and Adult Care Food Program, differences were significant only between the South and the Northeast. There were no statistically significant differences between the regions for the Women, Infants and Children program. 
Rural children and families who use the child nutrition programs resemble the profile of households in poverty across the country. Across all four programs, participating households are likely to be headed by a single, non-white female with less than a high school education. Only a small percentage of non-U.S. citizens participate, ranging from about 5 percent of rural households each for the National School Lunch, School Breakfast, and Child and Adult Care Food programs to 8 percent for WIC.

\section{Conclusion}

For many rural households across the country, particularly in the South, federal child nutrition programs are helping poor children meet their basic needs for nutritious meals and snacks. The disproportionate rates of participation by rural American households reflect the higher rates of poverty and food insecurity found in rural areas. ${ }^{9}$ They also reflect unique challenges poor rural families face in locating affordable food. Both the quantity and quality of food available to rural families can be limited by living in food deserts-communities with access to few grocery stores. ${ }^{10}$ The food in rural grocery stores is often more costly because of families' distance from major food distribution centers and lack of competition. ${ }^{11}$ Traveling to more affordable stores, food pantries, and soup kitchens is constrained by limited transportation options. ${ }^{12}$ Federal food assistance, particularly in schools and child care programs, provides important access to nutritious food for children.

Yet many rural children are not taking advantage of these programs. There are several barriers unique to rural areas that might affect participation. Rural areas lack public transportation; schools serving poor communities sometimes fail to meet the 50 percent eligibility requirement of some programs because they have large catchment areas that include communities where poverty is lower; and program operating costs can be higher for small rural schools and child care programs. These factors may explain the failure of the programs to reach the rural children who need them. ${ }^{13}$

With the economic recession and associated unemployment hitting rural areas particularly hard, ${ }^{14}$ the population of rural households eligible for child nutrition programs is likely to expand beyond the poor children that traditionally participate in the program. Although there are signs that participation is beginning to increase, need continues to outpace participation. ${ }^{15}$ Among rural families experiencing poverty for the first time, the problems of stigma and lack of program awareness may make expanding participation rates particularly challenging. As Congress takes up reauthorization of the child nutrition bill, it is important to recognize both the need for and the benefit of the programs in rural America and to examine the barriers to participation and effective delivery of the programs in rural communities.

\section{Data Used}

Data used for this brief are from the U.S. Bureau of the Census's Current Population Survey, including the Food Security Supplement (December 2007). The set of items analyzed asks households indirectly about their child or family's participation in several child nutrition programs during the last 30 days. These items ask if "(your child/any children in the household) receive free or reduced-cost lunches at school" from the National School Lunch Program; if "(your child/ any children in the household) receive free or reduced cost breakfasts at school" from the School Breakfast Program; if "(your child/any children in the household) receive free or reduced-cost food at a day-care or Head Start program" from the Child and Adult Care Food Program; and if "any (women/women or children/children) in this household get food through the WIC program."

\section{Endnotes}

1. U.S. Department of Agriculture Economic Research Service, "Federal Nutrition Assistance At a Glance," The Food Assistance Landscape: FY 2008 Annual Report, Economic Information Bulletin no. 6-6 (April 2009). Analysis does not include adult day care programs.

2. According to the December 2007 U.S. Census Bureau Food Security Supplement of the Current Population Survey, there are 14.2 million households that are income-eligible for these programs, with incomes less than 185 percent of the federal poverty threshold, and 11.4 million of these live in urban or suburban (metropolitan) areas. This represents 32 percent of metropolitan households with children. However, in rural areas, 45 percent of households with children are eligible.

3. Kristin Smith and Sarah Savage, "Food Stamp and School Lunch Programs Alleviate Food Insecurity in Rural America." Fact Sheet No. 5 (Durham, NH: Carsey Institute, University of New Hampshire, 2007), 1.

4.Income eligibility is based only on household income. Counting households with incomes less than 185 percent of the federal poverty threshold as a measure of program eligibility captures both the households that are eligible for reduced-price meals (if income is between 130 percent and 185 percent of the threshold) and households eligible for free meals (if income is less than 130 percent). However, it produces only a rough estimate of households that are eligible. Other program requirements may limit participation by otherwise eligible households.

5. Low rates of participation for the Child and Adult Care Food Program may also be due to the lack of awareness by parents participating in the survey that their children were attending a participating program. 
6. Kendall Swenson, "Child Care Arrangements in Rural and Urban Areas" (Washington, DC: Office of the Assistance Secretary for Planning and Evaluation, U.S. Department of Health and Human Services, 2008), available at http://aspe.hhs.gov/hsp/08/cc-urban-rural.

7. USDA Food and Nutrition Service, "How to Apply: WIC Eligibility Requirements," available at http://www.fns.usda.gov/ wic/howtoapply/eligibilityrequirements.htm.

8. Marybeth J. Mattingly, "Regional Young Child Poverty in 2008: Rural Midwest Sees Increased Poverty, While Urban

Northeast Rates Decrease," Issue Brief No. 6 (Durham, NH: Carsey Institute, University of New Hampshire, 2009).

9. U.S. Bureau of the Census, Current Population Survey, Annual Social and Economic Supplements (2007), available at http://www.census.gov/hhes/www/poverty/histpov/ hstpov8.xls; U.S. Department of Agriculture, Household Food Security in the United States. Economic Research Report, No. 11 (2004), No. 29 (2005), No. 49 (2006), and No. 66 (2007) (Washington, DC: USDA, Economic Research Service)

10. Troy Blanchard and Thomas Lyson, "Access to Low Cost Groceries in Nonmetropolitan Counties: Large Retailers and the Creation of Food Deserts," paper presented at the Measuring Rural Diversity Conference, Washington, DC, 2006. Available at http://srdc.msstate.edu/measuring/blanchard.pdf.

11. Julie N. Zimmerman, Sunny (Seonok) Ham, and Sarah Michelle Frank, "Is it Just Food? Geographic Differences in the Cost of Living" (Starkville, MS: Southern Rural Development Center, Mississippi State University, 2006), available at http://www.ers.usda.gov/Briefing/FoodNutritionAssistance/ Funding/RIDGEprojectSummary.asp?Summary_ID=149.

12. Dennis M. Brown, "Public Transportation on the Move in Rural America" (Washington, DC: USDA National Agricultural Library, 2008), available at http:// www.nal.usda.gov/ric/ricpubs/publictrans.htm.

13. Food Research and Action Center, "Meeting the Child Nutrition Challenges Facing Rural Areas" Child Nutrition Policy Brief 2 (Washington, DC: Food Research and Action Center), available at http://www.frac.org/pdf/ ruralpolicybrief.pdf.

14. U.S. Department of Agriculture Economic Research Service, "Rural America at a Glance, 2009 Edition," Economic Information Bulletin No. EIB-59, September 2009.

15. School Nutrition Association, "Saved by the Lunch Bell: As Economy Sinks, School Nutrition Program Participation Rises. An Analysis of School Nutrition Program Participation During the 2008/09 School Year" (National Harbor, MD: School Nutrition Association,
2008), available at http://www.schoolnutrition.org/ uploadedFiles/School_Nutrition/101_News/MediaCenter/ PressReleases/Press_Release_Articles/Press_Releases/ SavedbytheLunchBell.pdf.

\section{A C K N O W L E D G M E N T S}

The authors wish to express our appreciation to Mil Duncan and Terri Rippett at the Carsey Institute, Crystal FitzSimons at the Food Research and Action Center, and Barbara Ray at Hired Pen for their helpful comments and suggestions.

\section{A B OUT THE A T THOR S}

Barbara A. Wauchope is a research associate professor at the Carsey Institute at the University of New Hampshire (barb.wauchope@unh.edu).

Anne Shattuck is a doctoral student in sociology and a research assistant at the Carsey Institute (anne.shattuck@ unh.edu).

\section{UNIVERSITY
of NEW HAMPSHIRE}

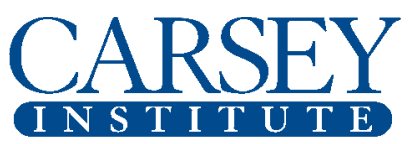

Building knowledge for families and communities

The Carsey Institute conducts policy research on vulnerable children, youth, and families and on sustainable community development. We give policy makers and practitioners timely, independent resources to effect change in their communities.

This work was supported by the Annie E. Casey Foundation's initiative to strengthen rural families, the W. K. Kellogg Foundation, and an anonymous donor.

Huddleston Hall

73 Main Street

Durham, NH 03824

(603) $862-2821$

www.carseyinstitute.unh.edu 